\title{
Relasi Simbol Pakaian “Anak Nagari” dalam Batarewai di Nagari Koto Gadang
}

\author{
Magfirah Ramadhani ${ }^{1}$, Erda Fitriani ${ }^{2}$ \\ 1,2 Universitas Negeri Padang \\ email: magfirahramadhani1996@gmail.com
}

\begin{abstract}
Abstrak
Penelitian ini bertujuan untuk mendeskripsikan dan menjelaskan relasi simbol pakaian anak nagari dalam batarewai di Nagari Koto Gadang. Penelitian ini dianalisis dengan menggunakan teori interpretivisme simbolik yang dikemukakan oleh Clifford Geertz. Penelitian ini menggunakan pendekatan kualitatif dengan tipe penelitian studi etnografi. Pemilihan informan dilakukan secara purposive sampling dengan jumlah informan 27 orang. Pengumpulan data dilakukan dengan cara observasi partisipasi pasif, wawancara mendalam, dokumentasi, serta validitas data dilakukan dengan triangulasi data. Data yang diperoleh dianalisis dengan menggunakan analisis interpretatif dengan langkah-langkah hermeneutik data, menginterpretasikan data, interpretatif dipresentasikan. Hasil penelitian dari relasi simbol pakaian anak nagari dalam batarewai adalah; 1) pakaian anak nagari yang belum menikah, 2) pakaian anak nagari yang baru menikah, 3) pakaian anak nagari yang sudah lama menikah, 4) pakaian anak nagari usia lanjut.
\end{abstract}

Kata Kunci: Batarewai, Pakaian Anak nagari, Relasi, Simbol.

\begin{abstract}
This study aims to describe and explain the relationship symbol of nagari children's clothing in batarewai in Nagari Kotogadang. This research was analyzed using the symbolic interpretivism theory proposed by Clifford Geertz. This study uses a qualitative approach with the type of ethnographic study. The selection of informants was done by purposive sampling with 27 informants. Data collection was carried out by means of passive participation observation, in-depth interviews, documentation, and data validity carried out by data triangulation. The data obtained were analyzed using interpretive analysis with hermeneutic data steps, interpreting data, interpretative presented. The results of the research of the symbol of the nagari children's clothing in batarewai are; 1) clothes of unmarried Nagari children, 2) clothes of newly married Nagari children, 3) clothes of nagari children who have long been married, 4) clothes of elderly nagari children.
\end{abstract} Keywords: Batarewai, Nagari Children's Clothing, Relationships, Symbols. 


\section{Pendahuluan}

Batarewai merupakan arak-arakan keliling kampung ketika Hari Raya Idul Fitri yang dilakukan oleh pengantin laki-laki baru atau pun sudah memiliki anak, yang terhitung sudah menikah selama satu tahun sebelum hari Raya Idul Fitri ${ }^{1}$. Tujuan dilaksanakannya batarewai ini adalah untuk memperkenalkan orang yang menjadi warga baru di Kotogadang dan sebagai wadah untuk mempererat tali silaturahmi masyarakat Kotogadang ${ }^{2}$. Dalam pelaksanaan batarewai, masyarakat Kotogadang terlihat menggunakan pakaian yang berbeda-beda. Pakaian yang digunakan sesuai dengan dasar falsafah adat Minangkabau yaitu, adat basandi syarak, syarak basandi kitabullah dan syarak nan mangato, adat nan mamakai. Pakaian yang digunakan dapat dikategorikan ke dalam bentuk pakaian tradisional.

Di Minangkabau pakaian yang berbeda digunakan oleh orang yang memiliki jabatan adat, namun dalam batarewai pakaian yang berbeda juga digunakan oleh anak nagari. Bagi masyarakat Kotogadang, anak nagari merupakan masyarakat yang tidak memiliki jabatan adat, artinya mereka bukan penghulu dan bukan bundo kanduang, tetapi anak nagari juga menggunakan pakaian yang berbeda-beda. Perbedaan pakaian ini dapat dilihat dari warna pakaian dan cara pemakaian atribut-atribut yang digunakan.

Pakaian yang digunakan dalam batarewai disesuaikan dengan status yang dimilikinya di dalam kehidupan bermasyarakat. Jika tidak digunakan sesuai dengan status yang dimiliki dalam masyarakat, maka akan mendapatkan sanksi sosial dari masyarakat Kotogadang. Dari empat nagari yang ada di Kecamatan IV Koto, hanya nagari Kotogadang yang menggunakan ketentuan berpakaian yang disesuaikan dengan status dan usia yang dimiliki oleh pemakainya. Secara umum pakaian anak nagari laki-laki terdiri dari baju cino, kain plekat, kopiah hitam, sarawa jawo. Sedangkan pakaian anak nagari perempuan terdiri dari baju kuruang basiba, kain panjang batik, kain sarung lasem, salodang, perhiasan.

Penelitian ini bertujuan untuk mendeskripsikan dan menjelaskan "Relasi Simbol Pakaian Anak Nagari dalam Batarewai di Nagari Kotogadang". Permasalahan yang akan peneliti kaji adalah penggunaan pakaian anak nagari yang berbeda-beda pada pelaksanaan batarewai. Umumnya pada nagari lain yang berada di Kecamatan IV Koto, tidak ada penetapan penggunaan pakaian yang digunakan anak nagari untuk menghadiri berbagai acara dan upacara adat. Sementara di Nagari Kotogadang untuk menghadiri acara adat khususnya batarewai, anak nagari menggunakan pakaian yang sudah ditetapkan, penggunaan pakaian ini disesuaikan dengan usia dan status yang dimilikinya dalam masyarakat. Perbedaan ini dapat dilihat dari warna pakaian dan cara pemakaian atribut-atribut yang digunakan. Pakaian anak nagari ini menjadi layak untuk diteliti karena pakaian dapat dilihat sebagai simbol dan yang hendak dikaji adalah relasi simbol dari pakaian adat anak nagari di waktu acara batarewai. Bertolak dari pokok persoalan tersebut, dapat diajukan pertanyaan penelitian: bagaimana relasi simbol pakaian anak nagari dalam pelaksanaan batarewai di Nagari Kotogadang, Kecamatan IV Koto, Kabupaten Agam?

Penelitian ini dianalisis dengan teori interpretatif oleh Clifford Geertz dianggap relevan dalam mengkaji relasi simbol pakaian anak nagari dalam batarewai. Menurut Geertz, kebudayaan itu adalah suatu pola makna-makna yang diteruskan secara historis yang terwujud dalam simbol-simbol, suatu sistem konsep yang diwariskan yang terungkap ke dalam bentuk-bentuk simbolis yang dengannya manusia berkomunikasi, melestarikan dan mengembangkan pengetahuan mereka tentang kehidupan ${ }^{3}$. Untuk memahami sebuah kebudayaan dalam suatu masyarakat, seseorang dituntut untuk mempelajari simbol-simbol yang terdapat pada masyarakat tersebut. yang memandang manusia sebagai pembawa produk

\footnotetext{
${ }^{1}$ Canang “Meneruskan Tradisi Hari Raya Di Kampuang” (Redaksi Canang, No.203, 2014). Hal 25-26.

${ }^{2}$ Canang "Patah Tumbuah Hilang Baganti” (Redaksi Canang, No.204, 2014). Hal 52.

${ }^{3}$ Ahmad F. Saifuddin. 2006. Antropologi Kontemporer. Jakarta: Kencana. Hal 307.
} 
sekaligus subjek dari suatu sistem tindakan dan simbol berlaku sebagai sarana komunikasi untuk menyampaikan pengetahuan, pesan-pesan, simbol dan pedoman untuk bertindak dan berprilaku.

\section{Metode Penelitian}

Penelitian ini dilakukan di Nagari Koto Gadang, Kecamatan IV Koto, Kabupaten Agam. Koto Gadang merupakan satu-satunya nagari di Minangkabau yang melakukan batarewai saat hari raya Idul Fitri. Dalam pelaksanaan batarewai tidak hanya pemuka adat, tetapi warga yang tidak memiliki jabatan adat atau anak nagari juga menggunakan pakaian yang telah ditetapkan, pakaian yang digunakan disesuaikan dengan status dan usia yang mereka miliki. Di daerah atau nagari yang berada di sekitar Nagari Koto Gadang tidak ada penetapan pakaian yang digunakan anak nagari untuk menghadiri berbagai acara adat. Penelitian ini dilakukan dengan pendekatan kualitatif tipe etnografi. Teknik pengambilan informan yaitu dengan purposive sampling ${ }^{4}$. Penarikan informan penelitian dilakukan dengan sengaja dan peneliti menentukan sendiri kriteria informan penelitian yaitu orang yang terlibat dalam batarewai. Adapun kriteria informan adalah orang yang terlibat dalam batarewai: elite tradisonal setempat yang terdiri dari ninik mamak, alim ulama, cadiak pandai dan bundo kanduang. Selain itu, informan juga diambil dari, ketua Yayasan Amai Setia, Wali Nagari Kotogadang, dan anak nagari. dalam hal ini bundo kanduang yang menjadi informan kunci karena, bundo kanduang yang lebih memahami makna dan cara penggunaan pakaian anak nagari dalam batarewai. Setelah melakukan penelitian informan berjumlah 20 orang yaitu, penghulu 3 orang, bundo kanduang 2 orang, niniak mamak 3 orang, wali nagari 1 orang, ketua Yayasan Amai Setia 1 orang, dan anak nagari 10 orang.

Teknik pengumpulan data yang dilakukan penelitian ini adalah dengan menggunakan observasi, wawancara, dan studi dokumentasi. Jenis observasi dalam penelitian ini adalah observasi pasif, dimana peneliti tidak terlibat langsung didalam objek penelitian. Observasi pasif, sewaktu pengumpulan data peneliti hanya mengamati aktivitas informan dalam pelaksanaan batarewai, serta mengamati lingkungan sekitar, kondisi tempat dan lingkungan yang sedang terjadi. Wawancara yang dilakukan peneliti adalah wawancara mendalam (Indept interview) dan wawancara bersifat bebas. Wawancara mendalam dilakukan kepada setiap informan yang dipilih dalam puposive sampling, pertanyaan yang diberikan kepada informan sesuai dengan pedoman wawancara yang telah disediakan. Dengan poin-poin wawancara yaitu, pelaksanaan batarewai, orang yang terlibat, simbol pakaian, konsekuensi dalam pelaksanaan batarewai. Poin- poin wawancara tersebut dikembangkan lagi dalam bentuk pertanyaan-pertanyaan yang terkait dengan relasi simbol pakaian anak nagari dalam batarewai. Untuk melengkapi data dokumentasi dilakukan dengan mengambil foto-foto, merekam suara, atau pun merekam video, catatan harian observasi dan catatan harian wawancara terkait dengan pelaksanaan batarewai. Untuk menguji keabsahan data peneliti menggunakan teknik triangulasi data. Jenis triangulasi yang digunakan dalam penelitian ini yaitu triangulasi sumber. Data yang diperoleh di lapangan dianalisis mengacu pada model analisis etnografi yang diperkenalkan Clifford Geertz ${ }^{5}$ yang terdiri dai tiga komponen yaitu, hermeneutik data, menginterpretasikan data, dan interpretatif direpresentasikan.

\footnotetext{
${ }^{4}$ Burhan Bungin.2003.Data Penelitian Kualitatif. Jakarta. PT Rsaja Grafindo Persada. Hlm. 53

${ }^{5}$ Suwardi Endraswara. 2012. Metodologi Penelitian Kebudayaan. Yogyakarta: Gajah Mada University Press. Hlm. 123.
} 


\section{Hasil dan Pembahasan}

\section{Hasil}

Dalam pelaksanaan batarewai terdapat relasi antara simbol pakaian dengan status yang dimiliki oleh anak nagari Kotogadang, relasi tersebut terlihat pada perbedaan atribut pakaian yang dipakai ketika batarewai yang dikelompokkan menjadi, 1) pakaian anak nagari yang belum menikah, ditandai dengan celana dan rok berwarna kuning kecoklatan dengan cara pemakaian selendang disilangkan pada bagian dada dan kain plekat berbentuk segitiga yang diikat ke pinggang; 2) pakaian anak nagari yang baru menikah, ditandai dengan celana dan rok berwarna merah, khusus untuk perempuan menggunakan motif berbunga-bunga yang lebih menonjol. Untuk pemakaian selendang dan kain plekat disandangkan di bahu; 3) pakaian anak nagari yang sudah lama menikah, ditandai dengan warna coklat tua, dengan pemakaian selendang di sandangkan di kedua bahu dan kain plekat dilipat menjadi dua disandang di bahu sebelah kanan saja; 4) pakaian anak nagari lanjut usia, ditandai dengan warna pakaian dominan hitam. Untuk pemakaian selendang, unjung selendang sebelah kanan dililitkan ke ketiak dan ujung selendang sebelah kiri dilepas atau dijuntaikan. Untuk pemakaian kain plekat dipakai dengan cara dililitkan ke leher.

\section{Pembahasan}

Menurut Geertz simbol dapat dilihat sebagai konsep-konsep yang dianggap oleh manusia sebagai pengkhasan sesuatu yang lain yang mengandung kualitas-kualitas analislogis atau melalui asosiasi-asosiasi dalam pikiran dan fakta. Selain itu manusia memberikan makna kepada setiap kejadian, tindakan atau objek yang berkaitan dengan pikiran, gagasan dan emosi. Penggunaan pakaian dalam batarewai menunjukan adanya relasi atau hubungan antara simbol yang digunakan dengan status yang dimiliki. Masyarakat yang melihat arakarakan juga memberikan makna terhadap simbol pakaian yang digunakan anak nagari sebagai identitas diri.

Simbol bertujuan mempelajari dan meneliti proses, yang dengan proses itu manusia memberikan makna kepada dunia mereka dan tindakan mereka. Dalam prosesi batarewai masyarakat juga memberikan makna atas simbol pakaian yang digunakan, cara pemakain atribut pakaian memberikan makna atau arti yang berbeda. Simbol yang dipakainya juga mempengaruhi tindakan mereka sebagai status yang di miliki, sehingga masyarakat juga mampu menginterpretasi makna dari simbol tersebut dan apa kaitannya simbol yang digunakan dengan simbol yang dimiliki.

Dari perbedaan warna dan cara pemakaian atribut batarewai dari anak nagari Kotogadang, memiliki arti dan makna yang dipahami oleh masyarakat setempat sebagai simbol dari status yang dimilikinya. Dari simbol tersebut masyarakat mampu menginterpretasikan identitas diri dan status dari seseorang. Kesalahan dalam penggunaan atribut atau simbol dalam pakaian batarewai juga akan mengakibatkan kesalahan pemahaman makna yang ditanggkap oleh masyarakat. Sehingga terbentuknya relasi simbol atau hubungan simbol dengan status yang dimiliki seseorang, seperti simbol yang menunjukkan seseorang masih gadis/ bujang, baru menikah, sudah lama menikah, janda/ duda, ataupun usia lanjut. Semua itu dapat diketahui dari atribut pakaian yang dikenakan ketika batarewai.

\section{Kesimpulan}

Dalam pelaksanaan batarewai terdapat relasi antara simbol pakaian dengan status yang dimiliki oleh anak nagari Kotogadang. Adapun relasi simbol pakaian anak nagari dalam batarewai terlihat ketika arak-arakan berlangsung, pada arak-arakan inilah tampak perbedaan 
warna dan cara pemakaian atribut batarewai dari anak nagari Kotogadang, masing-masing atribut pakaian memiliki arti dan makna yang dipahami oleh masyarakat setempat sebagai simbol dari status yang dimilikinya.

Dari simbol tersebut masyarakat mampu menginterpretasikan identitas diri dan status dari seseorangDari hasil penelitian yang sudah dilakukan, peneliti mendskripsikan tentang simbol pakaian anak nagari dalam batarewai di Nagari Kotogadang serta relasi simbol pakaian yang digunakan dalam batarewai. Diharapakan dengan adanya penelitian ini, dapat menjadi pedoman penelitian tahap lanjut dari sudut pandang yang berbeda. Dalam rangkaian prosesi batarewai masih terdapat fokus yang belum dikembangkan seperti fungsi dari anak nagari dalam batarewai, agar menjadi saran untuk penelitian selanjutnya.

\section{Daftar Pustaka}

Bungin, Burhan.(2003). Data Penelitian Kualitatif. Jakarta. PT Raaja Grafindo Persada.

Canang. (2014). Meneruskan Tradisi Hari Raya di Kampuang . Jakarta: Redaksi Canang.

Canang. (2014). Patah Tumbuah Hilang Baganti. Jakarta: Redaksi Canang.

Saifuddin, Ahmad F. (2006). Antropologi Kontemporer. Jakarta: Kencana.

Suwardi Endraswara. (2012). Metodologi Penelitian Kebudayaan. Yogyakarta: Gajah Mada University Press. 